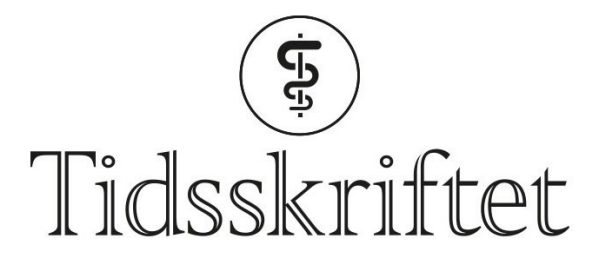

DEN NORSKE LEGEFORENING

\title{
Folkehelsepioner og sjaman
}

ESSAY

\section{EIVIND MELAND}

E-post: eivind.meland@uib.no

Eivind Meland er spesialist i allmennmedisin og professor emeritus ved Institutt for global helse og samfunnsmedisin, Universitetet i Bergen.

Forfatteren har fylt ut ICMJE-skjemaet og oppgir ingen interessekonflikter.

James R. Walker (1849-1926) var lege og folkehelseaktør, etnograf og folklorist. Gjennom sitt virke kom han i nær kontakt med det amerikanske urfolkets religiøse ledere og medisinmenn. Han ble selv opplært og innviet som sjaman i lakotanasjonen. Kan vi moderne medisinmenn lære noe av deres åndelighet, sjamanisme og samfunnspraksis?

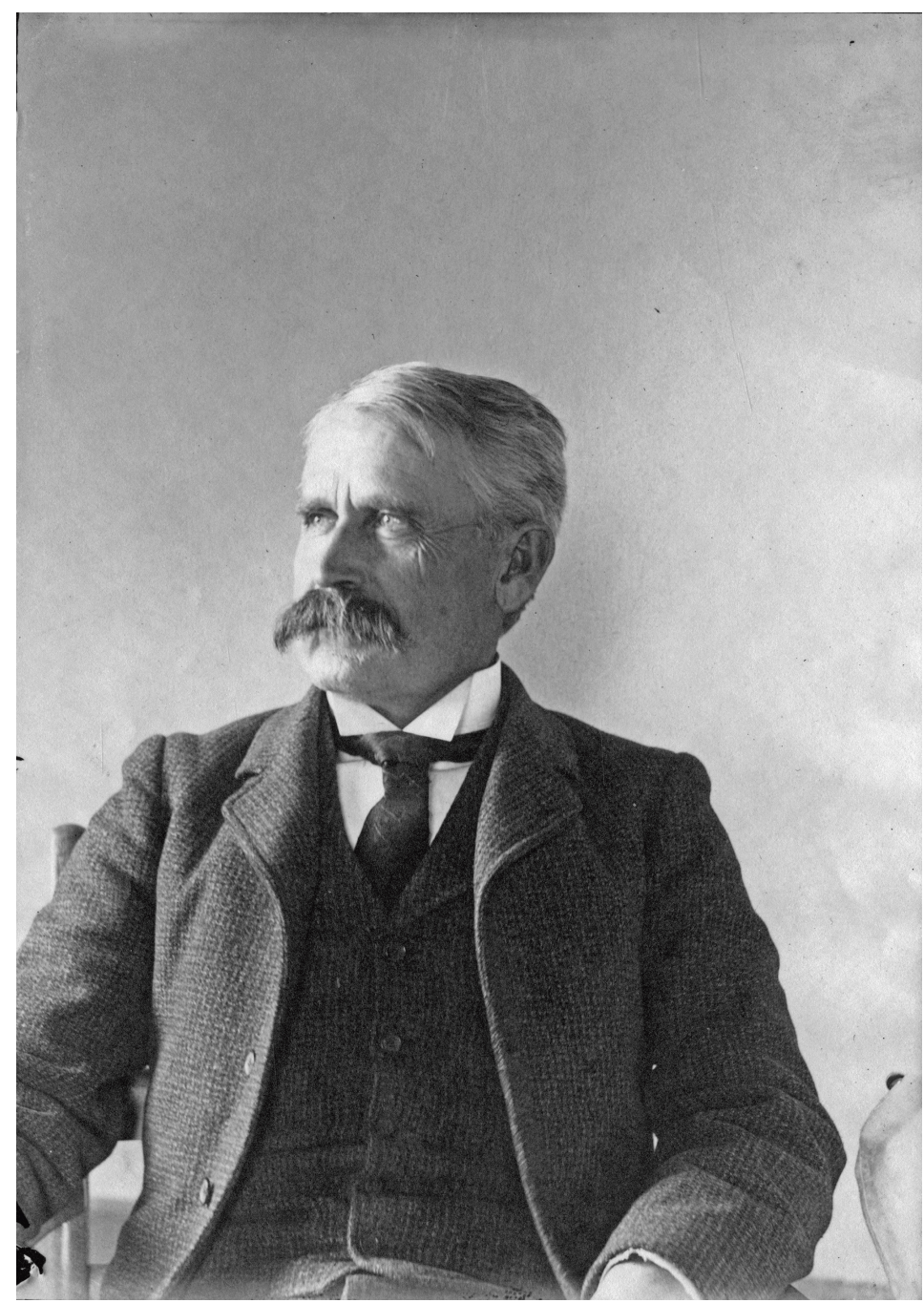


James Riley Walker arbeidet i mange år som lege i urfolkreservater i Midtvesten i USA. Han gjorde en bemerkelsesverdig innsats i folkehelsearbeid mot tuberkulose og ble opplert og akseptert som sjaman og medisinmann. Foto: Stephen H. Hart forskningssenter ved History Colorado

James Walker ble født i en tømmerhytte i Illinois i 1849 som den eldste i en familie som etter hvert talte ti barn (1). Før han fylte 15 år vervet han seg under borgerkrigen til Illinois' frivillige infanteriregiment. Der pådro han seg dysenteri, ble dimittert på grunn av sykdom og reiste hjem. Senere fullførte han etter hvert medisinsk embetseksamen i 1873. Han drev praksis i sin hjemby i noen år før han startet en mangeårig praksis stasjonert ved ulike reservater i Midtvesten. De første årene tjenestegjorde han i chippewastammens reservat nord i Minnesota. Vinteren 1882/83 startet en koppeepidemi i reservatet. I sprengkulden gjorde Walker en heltemodig innsats med forpleining og karantene av de syke og vaksinering av de friske i området og i grenseområdene. Dette ble han senere hedret for av president Theodore Roosevelt (1858-1919).

Som administrativ leder av chippewareservatet hadde Walker blant annet ansvar for å begrense fyll, kriminalitet og destruktiv uorden i samfunnet. Han sloss mot mektige krefter, blant annet mot whiskylangere. I en konfrontasjon med slike var han autoritær, brukte våpen og såret en innfødt med et vådeskudd. Dette kunne endt med gjensidig våpenbruk og risiko for Walkers eget liv, og episoden førte til at han mistet tillit blant urbefolkningen og måtte fratre sin stilling.

I noen år drev han også en praksis nordøst i staten Washington, men denne er det få kjente skriftlige kilder fra. Det var hans innsats i Pine Ridge-reservatet i $ø$ r-Dakota fra 1896 som gjorde Walker kjent som kliniker, folkehelseaktør, etnograf og folklorist. Her moderniserte og kvalitetssikret han medisinsk praksis i en populasjon på nesten 7 ooo innbyggere, hvorav 4983 var fullverdige medlemmer av oglala lakota (sioux)-stammen (1).

\section{Folkehelsearbeid mot tuberkulose}

Da Walker kom til Pine Ridge, var tuberkuloseforekomsten høy, og dødeligheten i befolkningen var sterkt preget av dette. Det var en utbredt oppfatning på den tiden at halvparten av lakotastammen var tuberkulosesyke. Walkers epidemiologiske kartlegginger viste at dette var sterkt overdrevet (2). Han avdekket blant annet at kun 741 av de 4983 stammemedlemmene i reservatet var tuberkulosesyke, en prevalens på 14,9\%. Sykdommen hadde en årlig dødsrate på 2,5\%, nesten halvparten av den samlede dødsraten. Fødselsraten var for lav til å kompensere for den høye dødeligheten, slik at det var et årlig nettotap av liv på $1,2 \%$.

Han samarbeidet med sjamanene og lærte om deres praksis og sykdomsforståelse. Til gjengjeld lærte han dem om sin forståelse og evidensbaserte tenkning

Walker var årvåken overfor de sosiodemografiske årsaksfaktorene til den sterke insidensøkningen av sykdommen. Lakotastammen hadde, i likhet med andre urfolk på prærien i Midtvesten, levd et nomadisk liv i sine godt luftede tipier. Bålet var «spyttebakke», og telthudene ble godt luftet og rengjort etter relativt korte opphold på hvert sted.

Tuberkulose hadde forekommet blant dem i uminnelige tider, men aldri med en slik insidensrate som etter at de ble tvunget til fast bosted i tette, overbefolkede hus uten lufting og med dårlige sanitære forhold (2). 


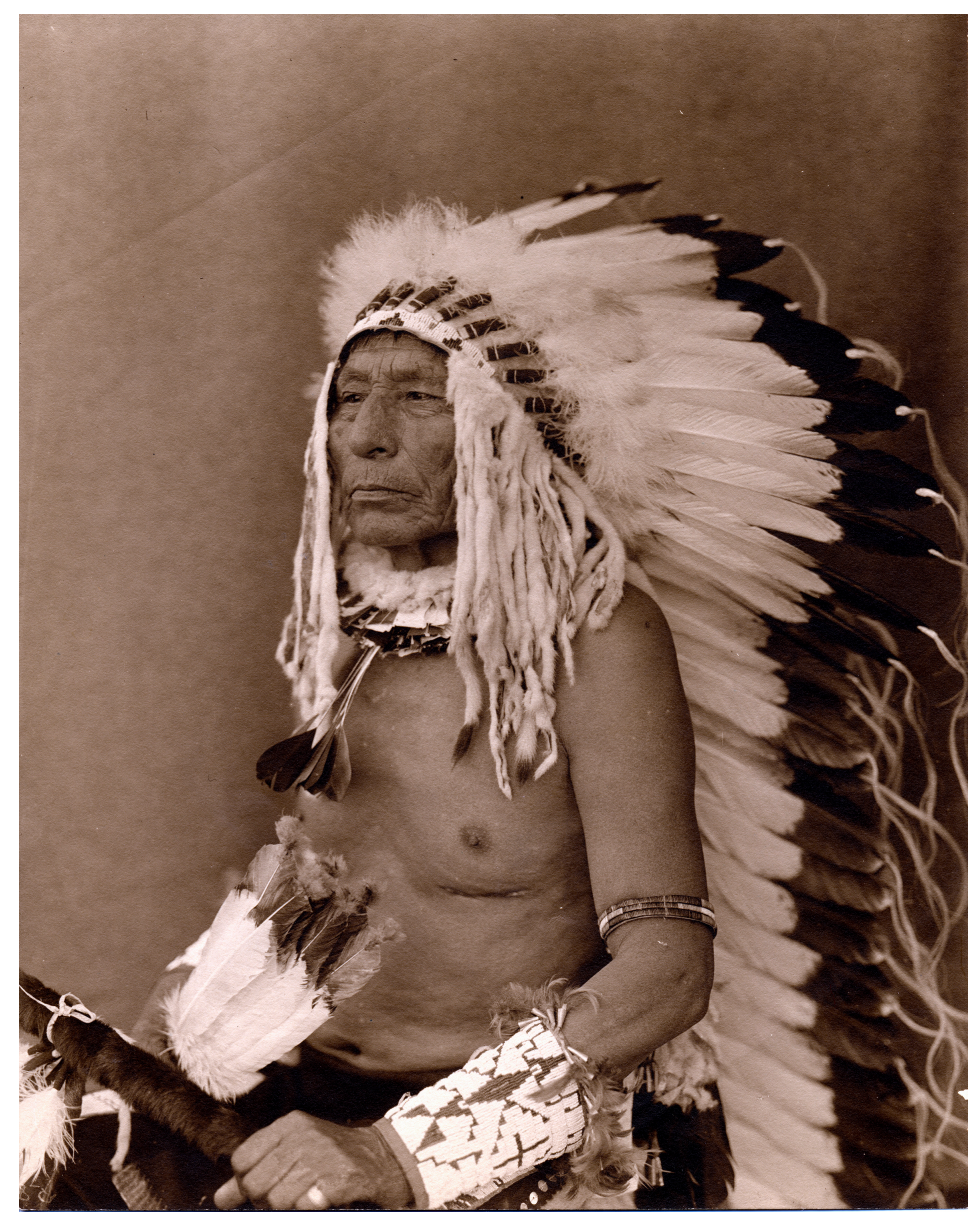

George Sword (Long Knife), her fra 1909, var ner venn av og leremester for James Walker. Han var sjaman, medlem av det medisinske selskapet Bear medicine og leder for vapnede styrker og jaktavdelinger. Sword konverterte og ble diakon i den kristne kirke i Pine Ridge (8). Foto:Joseph Kossuth Dixon / Indiana University Museum of Archaeology and Anthropology

Hans forebyggende folkehelsearbeid tok imidlertid et tydelig utgangspunkt i et såkalt kontagionistisk syn på sykdom, det vil si smitte som sykdomsårsak. Han observerte at sykdomsprevalens samvarierte med sosiale og sanitære forhold. Men det var observasjoner knyttet til smitte som dannet grunnlaget for folkehelsestrategien hans: Alle som ble smittet, hadde - uten unntak - hatt kontakt med tuberkulosesyke. «Hvis infisert materiale (fra ekspektorat og skrofuløse sår) blir hindret fra å komme i kontakt med de uinfiserte, vil sykdom bli forebygget», skrev han (2). Dette oppnådde han med å få de syke ut av overbefolkede hus og isolert i tipier som ble gjenreist. Her fikk de syke rikelig frisk luft og sol. Spytt og puss ble tilintetgjort, slik at uinfiserte ikke ble eksponert.

I løpet av fem år sank tuberkuloseprevalensen fra 14,9\% til 10,5\%. Dødeligheten ble nesten halvert (2). Walker ble igjen som eneste lege etter at hans kollega i reservatet fratrådte. Det kliniske arbeidet måtte prioriteres i et distrikt på størrelse med staten Connecticut, og folkehelsearbeidet ble vanskeliggjort. Prevalensen $\emptyset$ kte igjen, men ikke til samme nivå som i 1896. Walker foreslo da overfor myndighetene å bygge et sanatorium for de tuberkulosesyke. Disse planene ble etter hvert realisert.

\section{Etnografi og folkloristikk}

Walkers folkehelsearbeid hadde ikke vært mulig uten å vinne tillit blant urbefolkningen, deres ledere og medisinmenn. Han hadde drevet medisinsk arbeid blant urfolket i nesten 20 år og hadde satt seg som mål å lære dem å kjenne fra deres eget ståsted. Han samarbeidet med sjamanene og lærte om deres praksis og sykdomsforståelse. Til gjengjeld lærte han dem om sin forståelse og evidensbaserte tenkning. Blant annet klarte han å farge tuberkelbasiller og demonstrere sykdomsagens i mikroskop for dem (1). Det var antakelig en ny erkjennelse som var vanskelig å akseptere. 
Walker var en pioner i folkehelsearbeidet ved at han anerkjente betydningen av brukermedvirkning og en integrert helsetjeneste der også menneskets åndelige behov hadde plass

Det folkloristiske arbeidet hans besto i observasjon og intervjuer med de eldste i reservatet, men var først og fremst knyttet til opplæringen han fikk som sjaman. Selv om det fantes tidligere antropologiske studier av lakotastammen, klarte Walker fortjenestefullt å forstå symbolikk, myter, sangtekster og trosbegrunnelser og gi en helhetlig framstilling av kulturen. For å kvalifisere seg som sjaman måtte han gjennomgå soldansens fire nivåer. Gjennom det fikk han innblikk og erfaring med stammens spiritualitet (4). I dette arbeidet hadde han kontakt med flere sjamaner og profesjonelle historiefortellere. En av hans viktige læremestre var sjamanen George Sword. Sword hadde konvertert til kristen tro og var diakon i menigheten i Pine Ridge.

Ifølge Walker så lakotaene på seg selv som enestående og overlegne andre (4). Medmennesker som ikke aksepterte et slikt syn, var å regne som fiender. Graden av slektskap ble bedømt etter flere hierarkiske kriterier, og det var bestemte regler som hindret inngifte. En mann måtte betale kvinnens slekt en bestemt mengde klær av bøffelskinn for å kunne erverve seg henne. Kunne han ikke få en kone på en slik måte, måtte han enten tilrøve seg kvinnen fra en annen stamme eller ta til takke med en som ble budt ham. I slikt fall, og i de tilfeller kvinnen ikke hadde en egen tipi, sto han $\mathrm{i}$ takknemlighetsgjeld til kvinnen og måtte bygge en tipi til henne før deres første barn ble født. Det var hustruen som eide hudene fra bøflene som hennes mann hadde felt under jakt. Kjøttet ble delt blant alle i leiren. Hun eide også tipien og hadde beslutningsmyndighet innad i familien $(1,4)$.

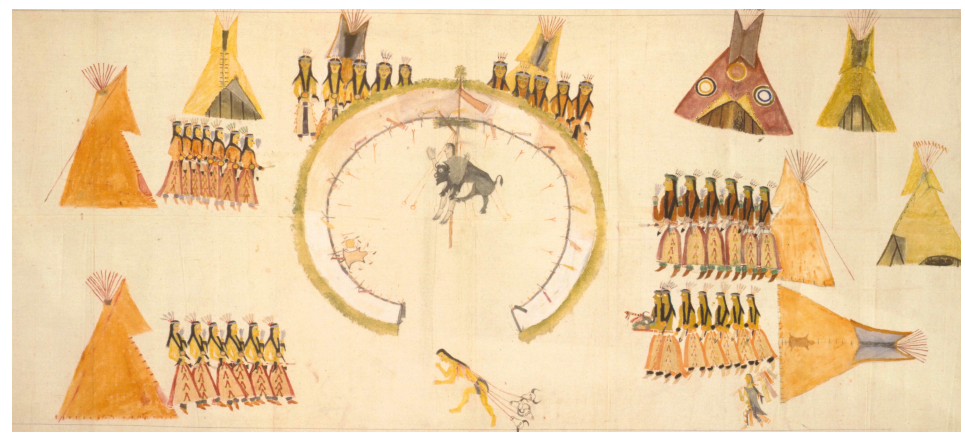

Den tredje dagen av soldansen, malt av Short Bull $i 1912$. Foto: Avdelingen for antropologi ved American Museum of Natural History (gjenstand 50.2/4063)

Ekteskapskontrakten var altså ikke bare avhengig av at de hadde innledet et seksuelt forhold, men ble anerkjent idet mannen hadde sørget for hennes sosiale sikkerhet. Kvinnen hadde både posisjon og flere rettigheter i samfunnet, men mannens maskuline makt besto $\mathrm{i}$ at han hadde eiendomsrett over henne og noen ganger også over hennes yngre søstre $(4,5)$.

I vestens moderne samfunn har vi mistet forståelsen av hvordan åndelighet var en nødvendig forutsetning for helse

Gjennom å delta i stammelivet fikk Walker innsikt i en hierarkisk samfunnsorganisering både mellom de forskjellige gruppene lakotaer og innad i hver gruppe. Det var bare betrodde menn som fikk plass i stammerådet, men de ble skiftet ut etter bestemte prosedyrer og funksjonstid. Det var knyttet sterk autoritet til lederne og spesielt til sjamanene. På den annen side var det stor selvbestemmelse om man ville tilhøre en gruppe eller ikke. Lederne hadde betydelig makt, men tjente de ikke folkets interesser, var fallhøyden stor. Sjamaner som hadde misbrukt sin makt til personlig vinning, kunne straffes med døden (4).

\section{Møte mellom religioner}

Walker kom til Pine Ridge seks år etter massakren ved Wounded Knee, en bekk som renner 
gjennom Pine Ridge-reservatet. I denne massakren hadde soldater fra det 7 . kavaleriregimentet, det samme regimentet som hadde lidd et forsmedelig nederlag ved Little Bighorn i 1876, åpnet ild mot ubevæpnede åndedansere (ghost dancers). 250-300 menn, kvinner og barn ble drept. Walker snakket med tidsvitner som fortalte detaljer om massakren. Hans beretninger om Wounded Knee slik urbefolkningen fortalte om det, er en del av Eli Ricker's tablets, en samling intervjuer med overlevende fra krigene med urbefolkningen (6). Black Elk, en medisinmann (holy man) i lakotastammen, er blitt sitert på at det ikke bare var mennesker som ble drept, men også en drøm om en bedre verden som tidligere hadde levd blant den amerikanske urbefolkningen (7).

Det største tapet urfolket og de hvite sammen led under koloniseringen av det nordamerikanske kontinentet, var kanskje at «den hvite mann» ikke maktet å forstå urbefolkningens naturreligiøse verdisyn. Kristentroen ble ikke sjelden fremmet på undertrykkende måter og ledsaget av forbud mot urfolkets religiøse riter (ramme 1).

\section{Ramme 1 Religiøse riter}

De religiøse ritene hadde som utgangspunkt at alt i naturen var besjelet. Menneskene kunne få hjelp gjennom å oppnå åndelig kontakt med et besjelet univers. De viktigste ritene var renselse i dampbad (innånding av vannets sjel slik at kroppen ble renset og styrket), søken etter visjoner (meditativ tilværelse alene for å motta tegn og åpenbaring fra åndeverdenen), piperøyking (seremoniell kontakt med åndene gjennom innånding av sjelskraft fra tobakk og visse urter) og soldansen (dans og sang over flere dager for å hente styrke og anerkjennelse fra solen og fra fellesskapet).

Walker anerkjente ikke bare lakotastammens verdisyn, men sluttet seg også til deres religion ved å utdanne seg til sjaman. Det er kanskje en prisverdig innsats (i et folkehelseperspektiv), men han ble anklaget både av kolleger ved Pine Ridge og av menigheten i reservatet for henholdsvis å vanære vitenskapelig medisin og kristentroen (1).

Trodde han på åndenes eksistens og på ritualenes blidgjørende effekter på åndene? Selv fortalte han at det var det naturreligiøse elementet i lakotaenes tro som fascinerte ham, og at han erfarte at deres ritualer kunne ha helende virkning på mennesker som led. Han ble akseptert som sjaman først og fremst fordi stammens egne sjamaner var få og gamle, og de erkjente at dette kunne være deres eneste mulighet til å formidle sin religion til etterslekten (8).

Walker gikk langt i å anerkjenne sjamanenes overnaturlige evner og mente at dette var uttrykk for en universell menneskelig kapasitet til å vinne innsikt i mysterier fra naturen utenfor menneskelig fornuft (8). Samtidig er det viktig å få frem at han også forsvarte vitenskapen. Han avslørte blant annet hvordan noen sjamaner anvendte lureri for å fjerne orm som angivelig skulle forårsake tuberkulose (1).

Vekten er i ferd med å forskyve seg fra å unngå ubehag og smerte til å leve oppreist i pakt med egne verdier

Den økumeniske bevegelsen blant verdens troende skjøt først fart et par generasjoner etter Walkers død, med det 21. kirkemøtet (det andre Vatikankonsil) i 1965 som ett av flere vendepunkt. Det ble en inspirasjonskilde også for forsonende samtaler mellom urfolkets religiøse ledere og katolske prester i reservatene i Sør-Dakota (9).

Samtaler gjennom sju år utviklet gjensidig respekt og anerkjennelse av at det i de to religionene var felles funksjonelle elementer i ritualer som med et ytre blikk kunne se ulike ut. Renselse i dampbad (sweat lodge) og skrifte og syndsforlatelse kan for eksempel fylle de samme religiøse behovene. $\boxminus ø n n$ og meditativ praksis er beslektet, og åpenbaringer har likeverdig plass i de to religionene (9). 
Selvsagt avslørte samtalene at det var skiller. Åndenes eksistens og ritualenes blidgjørende effekter var det vanskelig å enes om. Selv om kristentroen har etablert Den hellige ånd som en formidler mellom mennesket og Gud, har de kristne ikke forventninger om noen årsakssammenheng mellom ritualer og en blidgjørende effekt på ånden som hjelper oss $\mathrm{i}$ vårt daglige virke. Urfolkets religiøse ledere var imidlertid lite opptatt av årsaksforklaringer, men mest opptatt av effekter og funksjonalitet. Lakotafolket hadde heller ingen begrep for synd. De var mest opptatt av skam, og hvordan de håndterte skammen med forbedringsritualer og om nødvendig med sosial utestengelse (9).

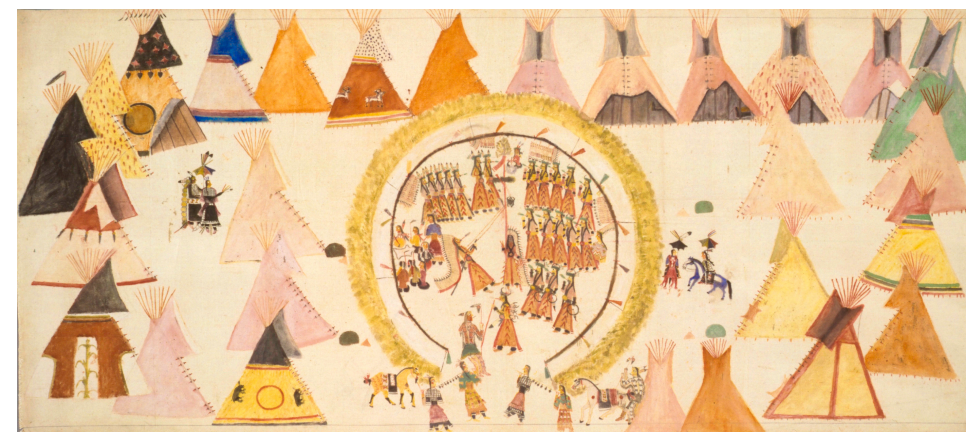

Den fjerde dagen av soldansen, malt av Short Bull $i 1912$.I soldansen måtte danseren demonstrere utholdenhet og også toleranse for selvpåført skade. Soldansens fire nivåer var bestemmende for sosial rangering. Det fjerde nivået (å danse som sjaman) ga den høyeste sosiale rangen som sjaman, åndelig leder og medisinmann $(1,5)$. Foto: Avdelingen for antropologi ved American Museum of Natural History (gjenstand 50.2/4064)

\section{En livsinnstilling å lære av?}

Walker var en pioner i folkehelsearbeidet ved at han anerkjente betydningen av brukermedvirkning og en integrert helsetjeneste der også menneskets åndelige behov hadde plass. Selv om vi i vestlig medisin besitter god dokumentasjon på betydningen av å understøtte og anerkjenne slike behov i helsetjenestene, er åndelig omsorg en ad hocvirksomhet i medisinen forbeholdt enkeltindivider som melder om behov for slik omsorg (10). Lakotastammen hadde en medisinsk forståelse der medisinen var hjemmehørende i en åndelig kulturell kontekst hvor kontakten med naturens ånder var en felles menneskelig forutsetning for helbredelse og læring.

I vestens moderne samfunn har vi mistet forståelsen av hvordan åndelighet var en nødvendig forutsetning for helse (10). Den sekulære kontrakten, som ble etablert i vestlige samfunn etter religionskrigene i det 17. århundret, har også representert en barriere mot å integrere åndelig omsorg og helbredelse i den teknisk-medisinske vitenskapen (11).

Selv er jeg blitt inspirert av Knud E. Løgstrup (1905-81). For meg er han en «moderne indianer» ved at han gjenoppdaget en naturreligiøs posisjon som er uavhengig av religiøs konfesjonstilhørighet. Løgstrups religionsfilosofi og sansefilosofi representerer en livsinnstilling som er uttrykk for en gammel visdom som har vært underslått i lang tid. Gjennom sansingen har vi et umiddelbart forhold til det vi opplever «der ute». Det kan fylle oss med takknemlighet nettopp fordi det ikke avhenger av vår anstrengelse, bare vår evne til å åpne oss fordomsfritt og uten forhåndsbestemte kategorier overfor det vi mottar. Vi kan glede oss over syns-, hørsels- og følelsesinntrykk ved umiddelbart å være sammen med det sansede. Det er ett av livets grunnvilkår som har forrang og gjør oss i stand til å velge livet hver morgen uten å reflektere og veie for og imot. Slik er verdens og skapelsens raushet $(12,13)$.

En slik livsinnstilling er på vei inn i vår vestlige kultur, foreløpig fra en outsiderposisjon. I medisinsk og psykoterapeutisk praksis er vekten i ferd med å forskyve seg fra å unngå ubehag og smerte til å leve oppreist i pakt med egne verdier. Naturen kan opplyse oss ved tilstedeværelse i meditativ praksis og i handlinger som er verdikongruente (14). Lakotafolkets soldans er et ritual til oppøvelse av kulturelle kjerneverdier: mot, gavmildhet, 
styrke og integritet. Det er verdier vi deler med dem.

\section{LITTERATUR:}

1. Walker JR, DeMallie RJ, Jahner EA. red. Lakota belief and ritual. Lincoln, NE: University of Nebraska Press, 1991.

2. Walker JR. Tuberculosis among the Oglala Sioux Indians. Am J Med Sci 19o6; 132: 6oo-5. [CrossRef]

3. Walker JR. The Sun Dance and Other Ceremonies of the Oglala Division the Teton Oglala. I: Wissler C, red. Sun Dance of the Plains Indians. Anthropolical Papers of the American Museum of Natural History. New York, NY: American Museum of Natural History, 1921: 51-224.

4. Walker JR. Oglala Kinship Terms. Am Anthropol 1914; 16: 96-109. [CrossRef]

5. Walker JR. Lakota society. Lincoln/London: University of Nebraska Press and the Colardo Historical Society, 1982.

6. Ricker ES. James R. Walker, Wounded Knee. I: Jensen RE, red. Voices of the American West: The settler and soldier interviews of Eli S. Ricker, 1903-1919. University of Nebraska Press, 2005: 24-7.

7. Brown D. Bury my heart at Wounded Knee. An Indian history of the American West. New York, NY: Bantam Books, 1970.

8. Walker JR. Introduction. I: Jahner EA, red. Lakota myth. Lincoln/London: University of Nebraska Press and the Colorado Historical Society, 1983: 1-40.

9. Stolzman W. The Pipe and Christ, Christian-Sioux Dialogue. Chamberlain, SD: Tipi Press, 1989.

10. Le Fanu J. Why us?: How Science Rediscovered the Mystery of Ourselves. Vintage, 2009

11. Cobb M, Puchalski CM, Rumbold B. Textbook of spirituality in health care. New York, NY: Oxford University Press, 2012.

12. Løgstrup KE. Den etiske fordring. Trondheim: Cappelens Forlag AS, 200.

13. Løgstrup KE. Skabelse og tilintetgjørelse. Religionsfilosofiske betragtninger. Viborg: Gyldendal, 2008.

14. Hayes S, Strosahl KD, Wilson KG. Acceptance and commitment therapy-The process and practice of mindful change. New York/London: Guilford Press, 2012.

Publisert: 29. juni 2020. Tidsskr Nor Legeforen. DOI: 10.4045/tidsskr.20.0013

(C) Tidsskrift for Den norske legeforening 2020. Lastet ned fra tidsskriftet.no 